\title{
Genetic Approach and Biometrical Association of Yield Attributing Traits in Chickpea (Cicer arietinium L.)
}

\author{
Anindita Roy ${ }^{1}$, Sanhita Ghosh ${ }^{2}$, S. Kundagrami ${ }^{3}$ \\ ${ }^{1,2,3}$ Department of Genetics and Plant Breeding, Institute of Agricultural Science, 51/2 Hazra Road, Kolkata-700019, University of Calcutta
}

\begin{abstract}
In this study, we assessed forty three chickpea genotypes (Cicer arietinium L.) at Calcutta University's experimental farm during rabi season 2014-2015 to estimate genetic parameters and nature of relationships of seed yield and its component characters. ANOVA revealed pronounced variation among the chickpea genotypes regarding all their eight characters studied. Higher magnitude of GCV and PCV along with high heritability as well as high genetic advance recorded for the traits viz., plant height, harvest index, pods per plant, seed yield per plant and 100 seed weight provide that these parameters were under the control of additive gene effects and effective selection could be possible for improvement of these characters. Positive and significant relationships were found with pods per plant, 100 seed weight and harvest index whereas the other traits showed positive but non-significant relationship with seed yield. Investigation regarding path analysis interpreted that all the traits, with the exception of plant height and branches per plant, had positive direct effect on yield. Pods per plant, 100 seed weight, harvest index, pod length and seeds per pod due to its highly positive both direct and indirect effect on seed yield could provide a good selection criteria for high yielding chickpea lines.
\end{abstract}

Keywords: Chickpea, genetic analysis, path, correlation, traits

\section{Introduction}

The demand of pulse is progressively increasing due to its diversified uses in developing countries, where speedy increase in population has already outstripped the available food supplies. Among all the pulses, chickpea (Cicer arietinum $L$.) is the third leading pulse in the world and first in the South Asia because of its intrinsic nutritional value and nitrogen fixing ability. Apart from Indian subcontinent, its range of cultivation extends from the Mediterranean basin to the west Asian and North American region, Eastern Africa and Latin America. Globally, chickpea is grown on about 13.2 million hectare area with a production of 11.62 million metric ton and an average productivity of $880.4 \mathrm{~kg} / \mathrm{h}$ (FAOSTAT, 2011). Despite its nutritional values and economic importance, the average yield of chickpea production in India is low and instable, which may be attributed to the evolution of cultivars with narrow genetic base making them vulnerable to constitutional stresses. Therefore, it is necessary to produce high yielding chickpea varieties considering their quantitative traits and make it more nutritious to supplement protein-deficient diets of the people than traditional varieties. The profitable yield can be obtained through simple selection of high yielding varieties according to breeding methods. Seed yield is a polygenically controlled complex character, direct selection of characters for seed yield could not be much more effective since there is presence of quantitative interaction; hence the importance should be given to yield contributing traits for selection of high yielding varieties (Singh, 2006). For an efficient breeding program, a survey of genetic variability with the help of suitable parameters like genetic coefficient of variability, phenotypic coefficient of variability, heritability and genetic advance are absolute necessary (Gul et al.,2013). The nature of relationships and their associations between seed yield and other traits are an also essential analytical procedure for improvement in grain yield. Correlation coefficients provide information of associations among two or more traits which aids in determining the most effective procedures for selection of superior genotypes, whereas path coefficient analysis enables us to determine the direct and indirect contribution of various traits toward yield. The present studies were undertaken to analyze the nature and magnitude of variability for seed yield and its components and to ascertain the association between seed yield and its related components for evolving superior high yielding chickpea varieties.

\section{Materials and Methods}

This study included forty three chickpea lines which are collected from NBPGR, some from Berhampore and some of them were local collection. The experiment was carried out Experimental Farm of University of Calcutta at Baruipur, South 24 Parganas during rabi season from middle week of November, 2014 to first week of April, 2015. The experiment was laid out in Randomized Block Design (RBD) with three replications. Each genotype was grown in a single row of $4 \mathrm{~m}$ length with a row to row spacing of 30 $\mathrm{cm}$ and $10 \mathrm{~cm}$ from plant to plant. Normal inter-culture operation where practiced throughout the growing periods. Harvesting of all genotypes were carried out manually at 130 days after planting. Data was recorded on five randomly selected plants from each replication for eight traits like :Plant height, Branches/ Plant, Pods/Plant, Pod length, Seeds/Pod,100 Seed weight, Harvest index and Seed yield /Plant. Following data collections, the data obtained on various agro morphological characters were subjected to various analyses by applying standard statistical techniques. Analysis of variance (ANOVA), coefficient of variability, broad sense heritability and genetic advance analysis were worked out according to the following method of Johnson et al. (1955), correlation study were done as per Pearson's correlation analysis and path coefficient analysis suggested by Dewey and $\mathrm{Lu}$ (1959).

\section{Volume 5 Issue 7, July 2016




\section{Results and Discussions}

Knowledge of genetic variation is a prerequisite for any improvements in traits as it helps to understand the magnitude of genetic variability which provides the basis for effective selection.

\subsection{Analysis of variance}

The analysis of variance revealed substantial variability among the lines for all the eight traits studied as the mean sum of squares showed significant differences for all the traits except pod length and seeds per pod. The results are shown in Table 1. All the characters under study showed high range of variation due to diverse source of materials taken as well as environmental influence affecting the phenotypes.

\subsection{Parameters of Genetic variability:}

Genotypic and Phenotypic coefficient of variability, heritability, genetic advance and genetic advance as percent of mean estimates are presented in Table 2 . The coefficient of variability showed cumulative effects and higher magnitude among all the genotypes. The estimates of variation revealed that GCV was smaller than PCV indicating that the apparent variation was not only due to genetic changes but also due to the favorable influence of environment. This environmental effect could be due to heterogeneity in soil fertility status and other unpredictable factors (S. K. Yadav et al. 2015). GCV was estimated to be high for branches per plant, seed yield per plant, pods per plant, harvest index, pod length \& 100 seed weight. Estimates of PCV showed a similar trend for all the above mentioned traits. The results are in conformity with the earlier findings of Malik et al., (2009). Ali et al., (2002) and Parhe et al.,(2014). The high values of GCV for branches per plant, seed yield per plant, pods per plant \& harvest index suggested that the traits may be under genetic control rather than the environment; hence these traits might be further improved through selection.

Heritability provides the assessment of amount of transmissible genetic variability from parent to offspring, happens to be the most important basic component that determines the genetic response to selection (Kumar G et al., 2015). The heritability estimates were found to be high for 100 seed weight, harvest index, plant height and pods per plant, moderate for pod length, seeds per pod and the lowest value was branches per plant. Traits with higher value of heritability indicated little environmental contribution to the traits thus having a potential for large genetic determination whereas, low heritability indicated that the characters were highly influenced by environmental effect. These findings are in accordance with the results of Sidramappa et al., (2008), Khan et.al., (2011) and Mushtaq et al.,(2013).

The estimates of genetic advance help to understand the type of gene action involved in the expression of various polygenic traits. The expected genetic advance of chickpea was highest for plant height (18.85) followed by harvest index (17.41) and pods per plant (15.59) while the remaining characters exhibited moderate to very low value. These results were in consonance with Monpara et al., (2013)and Ghaffar et al., (2015). The high value of genetic advance indicates additive gene action whereas low values indicate non-additive gene action. But genetic advance as percent of mean faciallated more precise result for various traits in comparison to genetic advance. The highest genetic advance as percent of mean were recorded for branches per plant (29.18) followed by pods per plant (23.56), seed yield per plant ( 21.25 ), harvest index (18.52), 100 seed weight (15.52).

According to Shumet and Addisu 2015, heritability alone provides no indication to make an efficient selection of individual genotypes for genetic improvement. Heritability in combination with intensity of genetic advance of the character provide good scope for further improvement in advance generation (Burton,1952). High heritability with high genetic advance as percent of mean obtained for the traits like pods per plant, harvest index \& 100 seed weight would prove quite effective since these characters seemed to be governed by additive gene action. An earlier work by Patil (1996) and Sidramappa (2003) reported similar observations. Singh et al., 2007, suggested that all these traits could be used as a criterion for selecting high yielding cultivars in future chickpea breeding program.

\subsection{Character Association}

\section{Correlation Studies:}

The correlation coefficient analysis is an important tool which provides symmetrical measurement of nature of interaction between various quantative traits to determinate the component characters on which selection can be based for genetic improvement in yield. Genotypic and Phenotypic Correlations among the traits studied pointed out the existence of several statistically significant relationships and are presented in Table 3 (i) and $\mathbf{3}$ (ii). At genotypic level, the attributes revealed that seed yield per plant showed highly significant and positive correlation with pods per plant, 100 seed weight, harvest index \& branches per plant while the remaining traits exhibited positive but nonsignificant genotypic correlation. At phenotypic level pods per plant, 100 seed weight \& harvest index exhibited significant and positive correlation coefficients with seed yield per plant. These results are in close conformity with Ramanappa et al., 2013 and Musthaq et al., 2013. Moreover in both genotypic and phenotypic, seed yield per plant exhibited highly significant and positive correlation with the traits of pods per plant, 100 seed weight and harvest index. The presence of positive and significant association between seed yield per plant and yield related traits suggests that seed yield can be improved through simultaneous selection of these traits ( Ramanappa et al., 2013). In this study, the phenotypic correlation were slightly greater than their corresponding geneotypic correlation value as the environment effect the expression of characters.

However, according to Musthaq et al., 2013 and Kumar et al., 2010 the breeder is always concerned for the selection of superior genotypes on the basis of positive phenotypic expression with seed yield because it would be of major use in direct selection respectively. 


\section{International Journal of Science and Research (IJSR) \\ ISSN (Online): 2319-7064 \\ Index Copernicus Value (2013): 6.14 | Impact Factor (2015): 6.391}

\section{Path Analysis}

Correlation study is not enough to explain the true association between the traits. So, from this aspect path coefficient analysis has emerged as a powerful and widely used technique to partition the observed correlation coefficient into direct and indirect effects of independent variables (yield) on the dependent (component) variable to provide clearer picture of character associations for formulating efficient selection strategy ( Dalbeer et al., 2013). Each yield component has a positive or negative contribution to overall expression of yield which could be indirect or direct through other component character. The direct and indirect effects of various yield components were given in Table 4. Path analysis revealed that most of the traits had positive direct effect on seed yield. The highest direct effect on seed yield was exhibited by pods per plant $(0.5327), 100$ seed weight $(0.3000)$, harvest index $(0.2955)$, pod length $(0.0402)$ and seeds per pod $(0.0100)$, indicating that they are main contributors to yield. Plant height (0.2102) had the highest positive indirect effect on seed yield followed by branches per plant (0.0756). These results are in accordance with Yücel 2004; Ciftci et al., 2004; and Güler et al., 2001. Most of the traits displayed positive indirect effect on seed yield through plant height, pods per plant, seeds per pod and 100 seed weight. All these major contributing traits to seed yield could therefore be used to improve seed yield in chickpea breeding program. However, from the residual effect of $\mathbf{0 . 6 2 9 3}$, it can be interpreted that the share of all other possible independent variables contributing to the seed yield need to be studied.

\section{Conclusion}

The selection of genotypes for sources of favorable yield and quality in any improved breeding program will depend on the consistency of a cultivar's performance over environments. This study was conducted to provide information on the performance of forty three chickpea genotypes based on yield and its attributing traits. The high genetic variability, heritability and genetic advance as percent of mean for the traits viz, pods per plant, harvest index, 100 seed weight, plant height and seed yield per plant could be the appropriate selection criteria for better seed yield in chickpea. Considering the correlation coefficient and path analysis of various components with seed yield per plant and its related traits, an ideal chickpea genotype would be one with high pods per plant, high $\mathbf{1 0 0}$ seed weight and high harvest index value. In the future breeding program, more emphasis should be given to these identified traits while making selection for higher seed yield in chickpea

Table 1: Mean sum of square of eight different characters in forty three lines of Chickpea:

\begin{tabular}{|c|c|c|c|c|c|c|c|c|}
\hline & $\begin{array}{c}\text { Plant Height } \\
(\mathrm{cm})\end{array}$ & $\begin{array}{c}\text { Branches/ } \\
\text { Plant }\end{array}$ & $\begin{array}{c}\text { Pods/ } \\
\text { Plant }\end{array}$ & $\begin{array}{c}\text { Pod } \\
\text { Length }(\mathrm{cm})\end{array}$ & Seeds/Pod & $\begin{array}{c}\text { 100 Seed } \\
\text { Weight }(\mathrm{gm})\end{array}$ & $\begin{array}{c}\text { Harvest } \\
\text { Index }\end{array}$ & $\begin{array}{c}\text { SeedYield / } \\
\text { Plant }\end{array}$ \\
\hline MS (R) & 1.04 & 4.14 & 108.21 & 0.02 & 28.28 & 6.34 & 20.85 & 20.36 \\
\hline MS (V) & $525.31^{* *}$ & $4.98^{*}$ & $362.88^{* *}$ & 0.40 & 0.48 & $44.35^{* *}$ & $371.65^{* *}$ & $53.27^{* *}$ \\
\hline MS (E) & 57.00 & 1.66 & 39.94 & 0.07 & 0.09 & 1.24 & 29.92 & 9.65 \\
\hline
\end{tabular}

$\mathrm{SOV}=$ Source of Variation, MS(R) = Replication Mean Sum Of Square, MS(V)=Variety Mean Sum Of Square, MS(E) = Error Mean Sum Of Square.

** Denotes 1\% level Of Significance, ${ }^{*}$ Denotes 5\% Level Of Significance.

Table 2: Estimates of GCV, PCV, H\%, GA, GA\% of mean for eight different characters in forty three lines of Chickpea:

\begin{tabular}{|c|c|c|c|c|c|c|c|c|}
\hline Parameters & $\begin{array}{c}\text { Plant Height } \\
(\mathrm{cm})\end{array}$ & $\begin{array}{c}\text { Branches/ } \\
\text { Plant }\end{array}$ & $\begin{array}{c}\text { Pods/ } \\
\text { Plant }\end{array}$ & $\begin{array}{c}\text { Pod } \\
\text { Length }(\mathrm{cm})\end{array}$ & $\begin{array}{c}\text { Seeds/ } \\
\text { Pod }\end{array}$ & $\begin{array}{c}\text { 100 Seed } \\
\text { Weight }(\mathrm{gm})\end{array}$ & $\begin{array}{c}\text { Harvest } \\
\text { Index }\end{array}$ & $\begin{array}{c}\text { SeedYield / } \\
\text { Plant }\end{array}$ \\
\hline GCV & 21.26 & 47.34 & 46.22 & 18.96 & 21.43 & 23.50 & 32.20 & 47.10 \\
\hline PCV & 24.84 & 74.87 & 54.12 & 23.92 & 28.22 & 24.49 & 36.18 & 60.74 \\
\hline H\% & 73.00 & 39.97 & 73.00 & 63.00 & 58.00 & 92 & 79.00 & 60.00 \\
\hline GA & 18.85 & 1.44 & 15.59 & 0.43 & 0.43 & 7.19 & 17.41 & 4.72 \\
\hline GA \% Mean & 10.81 & 29.18 & 23.56 & 8.36 & 8.87 & 15.52 & 18.52 & 21.25 \\
\hline
\end{tabular}

1.GCV $=$ Genotypic Coefficient Of Variation, 2.PCV=Phenotypic Coefficient Of Variation, 3.H\%=Heritability $\%$

Table 3: Genotypic (G) and Phenotypic (P) correlation among eight characters in forty three lines of Chickpea

\begin{tabular}{|c|c|c|c|c|c|c|c|c|c|}
\hline Traits & & $\begin{array}{l}\text { Plant } \\
\text { Height } \\
(\mathrm{cm})\end{array}$ & $\begin{array}{l}\text { Branches } \\
\text { /Plant }\end{array}$ & $\begin{array}{l}\text { Pods } \\
\text { /Plant }\end{array}$ & $\begin{array}{l}\text { Pod } \\
\text { length } \\
\text { (cm) }\end{array}$ & $\begin{array}{c}\text { Seeds / } \\
\text { Pod }\end{array}$ & $\begin{array}{c}100 \text { Seed } \\
\text { Weight } \\
(\mathrm{gm})\end{array}$ & $\begin{array}{l}\text { Harvest } \\
\text { index }\end{array}$ & $\begin{array}{c}\text { Seed } \\
\text { yield / } \\
\text { Plant }\end{array}$ \\
\hline \multirow[t]{2}{*}{ Plant Height $(\mathrm{cm})$} & $\mathrm{G}$ & \multirow[t]{2}{*}{1.00} & 0.044 & 0.109 & $0.365^{*}$ & -0.032 & 0.052 & -0.104 & 0.179 \\
\hline & $\mathrm{P}$ & & 0.286 & 0.161 & 0.104 & 0.248 & 0.179 & 0.006 & 0.013 \\
\hline \multirow[t]{2}{*}{ Branches /Plant } & $\mathrm{G}$ & & \multirow[t]{2}{*}{1.00} & $0.435^{* *}$ & 0.084 & 0.264 & 0.195 & $0.339 *$ & $0.330^{*}$ \\
\hline & $P$ & & & 0.223 & 0.260 & $0.389^{*}$ & 0.274 & 0.258 & 0.200 \\
\hline \multirow[t]{2}{*}{ Pods /Plant } & $\mathrm{G}$ & & & \multirow[t]{2}{*}{1.00} & 0.117 & $0.348^{*}$ & 0.254 & 0.253 & $0.627 * *$ \\
\hline & $\mathrm{P}$ & & & & -0.046 & 0.291 & 0.249 & 0.202 & $0.500^{* *}$ \\
\hline \multirow[t]{2}{*}{ Pod length $(\mathrm{cm})$} & $\mathrm{G}$ & & & & \multirow[t]{2}{*}{1.00} & 0.154 & 0.029 & -0.095 & 0.031 \\
\hline & $P$ & & & & & 0.294 & 0.164 & 0.007 & 0.033 \\
\hline \multirow[t]{2}{*}{ Seeds / Pod } & $\mathrm{G}$ & & & & & \multirow[t]{2}{*}{1.00} & 0.027 & -0.035 & 0.186 \\
\hline & $\mathrm{P}$ & & & & & & 0.177 & 0.027 & 0.082 \\
\hline 100 Seed Weight & $\mathrm{G}$ & & & & & & 1.00 & 0.035 & $0.422 * *$ \\
\hline
\end{tabular}

Volume 5 Issue 7, July 2016 www.ijsr.net

Licensed Under Creative Commons Attribution CC BY 
International Journal of Science and Research (IJSR)

ISSN (Online): 2319-7064

Index Copernicus Value (2013): 6.14 | Impact Factor (2015): 6.391

\begin{tabular}{|c|c|l|l|l|l|l|l|c|c|}
\hline (gm) & P & & & & & & & 0.104 & $0.304^{*}$ \\
\hline Harvest index & G & & & & & & & 1.00 & $0.433^{* *}$ \\
\cline { 2 - 9 } & P & & & & & & $0.304^{*}$ \\
\hline Seed yield / Plant & G & & & & & & & 1.00 \\
\end{tabular}

Table 4: Direct and indirect effects of different traits on seed yield in forty three lines of Chickpea

\begin{tabular}{|c|c|c|c|c|c|c|c|}
\hline Traits & Plant Height $(\mathrm{cm})$ & Branches/Plant & Pods/Plant & Pod Length $(\mathrm{cm})$ & Seeds/Pod & 100 Seed Weight (gm) & Harvest Index \\
\hline Plant Height $(\mathrm{cm})$ & -0.2102 & 0.0033 & 0.0582 & -0.0147 & 0.0003 & 0.0154 & -0.0307 \\
\hline Branches/Plant & 0.0091 & -0.0756 & 0.2317 & 0.0034 & 0.0026 & 0.0585 & 0.1003 \\
\hline Pods/Plant & -0.0230 & -0.0329 & 0.5327 & -0.0047 & 0.0035 & 0.0763 & 0.0747 \\
\hline Pod Length (cm) & 0.0767 & -0.0063 & -0.0621 & 0.0402 & 0.0015 & 0.0087 & -0.0280 \\
\hline Seeds/Pod & 0.0066 & -0.0200 & 0.1856 & 0.0062 & 0.0100 & 0.0080 & -0.0104 \\
\hline 100 Seed Weight (gm) & -0.0108 & -0.0148 & 0.1355 & 0.0012 & 0.0003 & 0.3000 & 0.0105 \\
\hline Harvest Index & 0.0218 & -0.0257 & 0.1346 & -0.0038 & -0.0004 & 0.0106 & 0.2955 \\
\hline
\end{tabular}

Residual effect is $\mathbf{0 . 6 2 9 3}$

\section{References}

[1] Addisu.F, and Shumet.T., 2015. Variability, Heritability and Genetic Advance for Some Yield and Yield Related Traits in Barley (Hordeum vulgare L.) Landraces in Ethiopia. International Journal of Plant Breeding and Genetics. 9: 68-76.

[2] Ali. S., Maher. B.A., Anwar. M. and Haqquan. M. A., 2002. Genetic variability for grain yield improvement in chickpea. Int. J. Agri. Biol. 4 (1),148-149.

[3] Burton, G.W., 1952. Quantitative inheritance in grasses. Proceedings of the 6th International Grassland Congress, August 17-23, Pennsylvania State College, USA., pp: 277-283.

[4] Ciftci, V., Toay, Doan.Y., 2004. Determining relationship among yield \& some yield components using path coefficient analysis in chickpea ( Cicer arietinum L.). Asian J. Plant. Sci. 3 : 632-635.

[5] Dalbeer, Nath Shiva, Verma O. P., Kavita, Kumar Kisan, 2015. Correlation and Path Coefficient Analysis for Yield Attributes in Lentil (Lence culinaris L.). International Journal of Science and Research (IJSR). 4(8),p.Id: 30071505

[6] Dewey. R.D. and Lu, K.H., 1959.A correlation and path coefficient analysis of components of crested wheat grass seed production. Journal of Agronomy. 51: 515518.

[7] FAOSTAT Website :- www.fao.org.

[8] Ghaffar.A. , Hussain. N., Aslam. M., Hussain. K., Irshad. M., Ahmad. M. and Naeem-ud-Din, 2015. Identification of superior hybrid through exploitation of hybrid vigour in chickpea (Cicer arietinum L.). Int. J. Adv. Res. Biol.Sci. 2(2): 180-184.

[9] Gul R., Khan H., Bibi M., Ain Q.U. and Imran B., 2013. Genetic analysis and interrelationship of yield attributing traits in Chickpea (Cicer arietinum L.). J. Anim. Plant Sci. 23(2): 521-526.

[10]Güler, M., M.S. Adak and Ulukan.H., 2001. Determining relationship among yield \& some yield components using path coefficient analysis in chickpea. Eur. J. Agron. 14 : 161-166

[11] Johnson. H. W., Robinson, H. F. and Comstock, R. E, 1955. Estimates of genetic and environmental variability in soybean. Agricultural Journal. 47: 214238.
[12] Khan.R., Farhatullah and Khan.H., 2011. Dissection of genetic variability and heritability estimates of chickpea germplasm for various morphological markers and quantitative traits. Sarhad J. Agric, Vol. 27, No. 1.

[13]Kumar .G. Vijay, Vanaja. M, Abrahum. Banu, Y. Anitha, N. Jyothi Lakshmi and Maheswari. M., 2015. Variability, heritability and genetic advance for quantitative traits in blackgrams (Vigna (L.) Hepper). Int J. Curr Sci. 17 : E 37- 42.

[14] Kumar. N. Vinay, Lavanya. G. Roopa, Singh . K.Sanjeev, and Pande. Parveen., 2010. Genetic association and path coefficient analysis in mungbean Vigna radiata (L.) Wilczek. AAB Bioflux, Volume 2, Issue 3.

[15] Malik SR, Bakhsh A, Ahsan MA, Iqbal U, Iqbal SM., 2009. Assessment of Genetic Variability and Interrelationship among some Agronomic Traits in Chickpea. International Journal of Agriculture and Biology. 12(1), 1814 - 9596.

[16] Monpara. A. B and Dhameliya. R.H., 2013. Genetic behavior of earliness related traits \& seed yield I chickpea (Cicer arietinum L.). Pak.J. Bio. Sc., 16 (18) : 955-959.

[17] Mushtaq .A. M, Bajwa. M.M and Saleem. M., 2013. Estimation of genetic variability and path analysis of grain yield and its components in chickpea (Cicer arietinum L.). Int. J. of Scientific \& Eng. Research. Vol. 4, Issue 1.

[18] Parhe. D. S, Harer. N. P and Nagwade. R. D., 2014. Investigation of genetic divergence in chickpea (Cicer arietinum L.). Int. J. life Sc., 9(2): 879-882.

[19] Patil, A.B., 1996. Inheritance studies on yield and yield components in desi x desi, desi x kabuli and kabuli $\mathrm{x}$ kabuli crosses of chickpea (Cicer arietinum L.). M.Sc.(Agri.) Thesis, Univ. Agric. Sci., Dharwad (India).

[20] Patil, S. B., 1996. Variability studies in segregating populations of chickpea. Legume Res., 13(1):36-46.

[21] Ramanappa.T.M., Chandrashekara. K. and Nuthan.D., 2013. Analysis of Variability for Economically Important Traits in Chickpea (Cicer arietinum L.). International Journal of Research in Applied, Natural and Social Sciences.,1: 133-140.

[22] Sahao, S. C., Mishira S. N., Mishia and R. S., 1990. Genetic variation in F2 generation of chilli capsicum. Newsletter 8: 29-30.

\section{Volume 5 Issue 7, July 2016 www.ijsr.net}




\section{International Journal of Science and Research (IJSR) \\ ISSN (Online): 2319-7064}

Index Copernicus Value (2013): 6.14 | Impact Factor (2015): 6.391

[23] Siddramappa, B., 2003, Relationship of phonological traits with productivity in chickpea (Cicer arietinum L.), M.Sc (Agri) Thesis, Univ. Agric. Sci., Dharwad (India).

[24] Sidramappa, Patil. S. A, Salimath.P.M. and Kajjidoni. S.T., 2008. Genetic variation for productivity and its population of chickpea. Karnataka J. Agric. Sci., 21: 488-490

[25] Singh S.P.,2006. Genetic variability and response to selection in chickpea (Cicer arietinum L.). Int. J. Plant Sci. 1(2): 232-233.

[26] Singh, S. P., 2007. Correlation and path coefficient analysis in chickpea (Cicer arietinum L.). Int. J. Plant Sci. 2: 1-4.

[27] Yadav. K. Sunil, Singh. K. Ashok, Pandey. Praveen and Singh. Smita., 2015. Genetic variability and direct selection criterion for seed yield in segregating generations of Barley ( Hordeum Bulgare L.,) American Journal of Plant Sciences, 6 : 1543-1549.

[28] Yücel, C., 2004. Correlation and path coefficient analysis of seed yield components in the narbob bean ( Vicia Narbonesis L.) Turk. J. Agric. For., 28 : 371-376.

Volume 5 Issue 7, July 2016 www.ijsr.net 